\title{
In an era of stalled reconciliation: the uncanny witness of Ray Lawrence's Jindabyne
}

\author{
ROSANNE KENNEDY
}

Ray Lawrence's Australian film Jindabyne is a powerful national allegory about the denial of historical responsibility and the politics of post-colonial apology across a 'traumatic contact zone' of historical injustice. ${ }^{1}$ Released in 2006, Jindabyne was produced during a period of stalled reconciliation in Australia. Like many nations in the past 20 years, Australia has been engaged in a painful and uneven process of coming to terms with historical injustice- a process that remains incomplete and unsettling. In 1991, the Council for Aboriginal Reconciliation, inaugurated under a federal Labor government, anticipated that reconciliation would be achieved by the centenary of Federation in 2001. In 1996, in what subsequently became a landmark event in the nation's attempt to respond to the divided legacies of settler-colonialism, a national inquiry was conducted into the forcible removal of Indigenous children from their families and communities. ${ }^{2}$ The final report, Bringing Them Home, found that the removal of children of mixed descent, with the aim of alienating them from their culture and assimilating them to white Australian culture, breached Australian common law and international human rights conventions. ${ }^{3}$ The national inquiry did not address issues of justice or responsibility. Instead, it documented Indigenous suffering and solicited an affective response from non-Indigenous Australians. By May 1997, when the national inquiry tabled its report calling for a national apology to the Stolen Generations, there had been a change of government. The then Liberal Prime Minister, John Howard, did not believe the current generation of Australians should be made to feel responsible for the past and notoriously refused to offer a national apology. Instead, he expressed his 'personal regret' for the suffering and hurt caused by past policies of child removal. For the next 11 years, no apology was forthcoming, and by the new

\footnotetext{
1 The phrase 'traumatic contact zone' is used by Kaplan, E. Ann (ed.) 2005, Trauma Culture: The politics of terror and loss in media and literature, Rutgers University Press, New Brunswick, NJ.

2 Wilson, Sir Ronald (ed.) 1997, Bringing Them Home: Report of the National Inquiry into the Separation of Aboriginal and Torres Strait Islander Children from their Families, Human Rights and Equal Opportunity Commission, Sydney.

3 Ibid, pp. 249-76.
} 
millennium, the reconciliation process had stalled. In a climate of widespread support for reconciliation generated by the national inquiry, Howard's refusal to apologise became a stain on the nation. In 2008, the first order of business for the new Labor government of Kevin Rudd, after opening Parliament on 13 February, was to offer a national apology to the Stolen Generations and their families and communities.

Rudd's and Howard's responses to a national apology were symptomatic of opposing tendencies that marked the reception of Bringing Them Home: on the one hand, an affective response grounded in empathy and identification, and on the other, denial and forgetting. The former response was expressed through the signing of 'Sorry Books', Bridge Walks for Reconciliation in 2000 and support for a national apology. The latter resulted in criticisms of the report and of the 'black-armband view of history', outrage at the claim of genocide and an insistence that 'the past remain in the past' ${ }^{4}$ These opposing responses are not, of course, surprising. As Dominick LaCapra reminds us, nations dealing with the unfinished business of the past must confront the problem of how to acknowledge and work through 'historical losses in ways that affect different groups differently' ${ }^{5}$ What is striking, however, is how little explicit discussion there has been of what is involved in working through the divided legacies of colonial dispossession, violence and forced assimilation in Australia. Indeed, the long-awaited apology was viewed widely as a necessary and uncomplicated matter of acknowledging the suffering caused by past policies, which would move the nation towards reconciliation. At the same time, the government rejected the national inquiry's recommendation for reparations such as monetary compensation, and Stolen Generations cases repeatedly failed in court. These events raise a number of questions: what is the value of apology without justice or reparation? Is an apology without reparation simply a onesided acknowledgment and expression of regret for suffering caused by past policies? Is an apology a performative act that allows the nation to forgive itself and achieve closure on a troubling past, while at the same time divorcing the past from continuing issues of Indigenous disadvantage?

Viewed in the context of the long decade of stalled reconciliation in Australia, and the issues raised by Bringing Them Home, Jindabyne is an especially rich film for analysis. Literary critic Mary Poovey argues that the value of cultural objects lies in their capacity to 'express an imaginary relation to a past that

\footnotetext{
4 Manne, Robert 2001, 'In denial: the Stolen Generations and the right', Quarterly Essay, vol. 1; Haebich, Anna 2000, Broken Circles: Fragmenting Indigenous families 1800-2000, Fremantle Arts Centre Press, Fremantle, WA.

5 LaCapra, Dominick 2001, Writing History, Writing Trauma, The Johns Hopkins University Press, Baltimore, pp. 44-5.
} 
can be remembered and a future that can be anticipated' ${ }^{6}$ Jindabyne, through its production of uncanny effects, brings to the surface what remains buried and unspeakable in 'white' Australia. The film explores the dominant white responses - denial and guilt - to historical injustice through parallel narratives, characterisation, shifting perspectives, repetition and mood. In particular, the film acts out the blockages and blindness that prevent non-Indigenous Australians from recognising their implication in a historical legacy of colonisation and dispossession on the one hand, and the presumption of guilt that accompanies an over-identification with the victim's pain and suffering on the other hand. By exploring these opposing 'white' subject positions, the film can be viewed as mediating the non-Indigenous public reception of the Bringing Them Home report and the issue of responding to historical injustice that it raises. By staging a climactic scene of rejected apology, the film invites viewers to consider the ideological, ethical and psychological assumptions underpinning the act of apology and the broader framework of reconciliation in a settler-colonial context.

Jindabyne achieves these effects by producing what I call uncanny witness: knowledge that is simultaneously familiar and strange. In Uncanny Australia, Ken Gelder and Jane Jacobs demonstrate that the uncanny is a particularly useful concept for exploring the contradictions and limits of national belonging in a settler-colonial nation such as Australia. For Freud, the anxiety of the uncanny was produced when a sense of familiarity and strangeness existed simultaneously. Living in post-colonial Australia might produce an uncanny sense of being simultaneously 'at home' and 'unsettled' for those who identify as 'white Australians' - a condition that is played out in Jindabyne. ${ }^{7}$ Gelder and Jacobs proposed that the ghost story was a particularly rich genre for investigating the effects of the post-colonial uncanny. They noted that, as of the late 1990s, Australian writers and filmmakers had 'not yet spectacularised the Australian ghost story', which 'remains a...marginal genre'.$^{8}$ Jindabyne - a significant contribution to this genre- bears witness to the ways in which the imagined Australian nation is haunted by an unresolved past.

My analysis of Jindabyne's uncanny witness is informed by a psychoanalytical understanding of testimony as a process of bearing witness to knowledge that we do not yet consciously possess. Shoshana Felman and Dori Laub drew on psychoanalysis to challenge the juridical conception of testimony as a transparent representation of the past. They introduced the notion of indirect testimony, productively proposing that

6 Poovey, Mary 2001, 'The twenty-first century university and the market: what price economic viability?', Differences, vol. 12, no. 1, p 12.

7 Gelder, Ken and Jacobs, Jane 1998, Uncanny Australia: Sacredness and identity in a postcolonial nation, Melbourne University Press, Melbourne, p. 23.

8 Ibid. 
[p]sychoanalysis rethinks the concept of testimony...by recognizing... that one does not have to possess or own the truth, in order to... bear witness to it; that speech as such is unwittingly testimonial, and that the speaking subject constantly bears witness to a truth that nonetheless continues to escape him, a truth that is, essentially, not available to its own speaker. ${ }^{9}$

A psychoanalytical approach is particularly fruitful for analysing the uncanny witness of a layered aesthetic text such as Jindabyne. As James Penny argues, '[p]ostcolonial criticism can only benefit from a posthumanist theory that views cultural production as a complex, dynamic, and ultimately undecidable artifact of conscious and unconscious processes'. ${ }^{10}$ While Jindabyne can fruitfully be read in relation to debates about reconciliation and apology in Australia, the film also suggests that responses to trauma cannot be explained entirely in terms of a socio-political inscription of cultural conflict in contemporary race relations. The film suggests that there are psychic processes at work in the individual that shape responses to events, including whether an event is interpreted as 'traumatic'. In terms of a psychoanalytic reading, it is worth noting that the film focuses on 'white Australian' responses to the past and to cultural conflict. The Indigenous characters are not developed and function primarily as a foil for the playing out of 'white' psychological and cultural dramas.

\section{H(a)untings: Jindabyne as post-colonial ghost story}

Jindabyne is a post-colonial Australian adaptation of a Raymond Carver short story 'So much water so close to home'. ${ }^{11}$ The film takes its name from a country town, Jindabyne, in the south-east of Australia. As the gateway to the Australian Alps, Jindabyne attracts tourists, who come to bushwalk, fish, ski and enjoy its man-made lake. Jindabyne is famous for the nearby Snowy Mountains Hydro-Electric Scheme - the largest and most complex engineering project in Australia. Undertaken in the postwar period, from 1949 to 1974, the scheme brought thousands of European immigrants to work on it and thus contributed to building a multicultural Australia. The Snowy Mountains web site provides a surprising and largely forgotten insight:

\footnotetext{
9 Felman, Shoshana and Laub, Dori 1992, Testimony: Crises of witnessing in literature, psychoanalysis, and history, Routledge, New York.

10 Penny, James 1998, The Psychoanalysis of Race, Edited by Christopher Lane, Columbia University Press, New York, p. 135.

11 Carver, Raymond 1977, 'So much water so close to home', Furious Seasons and Other Stories, Capra Press, Santa Barbara, Calif. Robert Altman produced a 'cinematic interpretation' of Carver's story in his film Short Cuts (1993).
} 
The original town and its inhabitants were relocated in the 1960s when the Snowy River was dammed as part of the Snowy Mountains Scheme, with only a handful of houses being moved to their new location. The remains of the old town lie submerged under Lake Jindabyne and can occasionally be glimpsed when lake levels are low. ${ }^{12}$

This uncanny tale is used to powerful effect in the film, providing a metaphor for historical dispossessions and repressed events that continue to haunt the present. ${ }^{13}$ Fishing at the lake, Stewart embellishes the tale, telling his wide-eyed young son, Tom, that the old town 'exists whole' at the bottom of the lake and the people still live there, rocking on their porches. A 'factual' version of this story - from a 1960s documentary about the town's history - is later presented to the schoolchildren.

The film opens with the sounds of electricity - wires fizzing, radio static and buzzing - signifying the impact of the hydro-electric scheme on the region. The first scene stages the off-camera rape and murder of a young Indigenous woman by a white man - a repetition of racial and sexual violence. Susan sings as she drives along a lonely country road on a perfect summer's day. An older man in an electrician's truck lies menacingly in wait, tracking her movements through binoculars, as if he owns the country and all that it contains. The spectator is implicated in his voyeurism: we first see Susan's face as it is framed by his binoculars, as he confirms that his prey is a lone, young Aboriginal woman. The scene unfolds through interlaced frames that build suspense: he spies on her, while she looks at him warily through the rear-view mirror. He speeds up aggressively, passes her and blocks the road with his truck. His method of trapping her references the violent colonial hunting of Aborigines off their land, as well as continuing racial and sexual violence. The racist nature of the sexual assault becomes clear later, when, in a parallel scene, the murderer nearly drives Claire off the road, but lets her pass. By figuring Susan as 'Indigenous' and the murderer as linked to the hydro-electric scheme, the narrative invites her murder to be read as an allegory of the violence that occurred in the process of dispossessing Indigenous people of their lands. The murderer, like the lake, is a figure that haunts the town, but he is never named, except through the name printed on his truck. As Ann Stoler points out, '[t]o be haunted is to be frequented by and possessed by a force that not always bears a proper name'. ${ }^{14}$ The murderer's violent act sets the post-colonial uncanny and its unsettling

12 Accessed at <http://www.snowymountains.com.au/Jindabyne.html > Water has multiple symbolic meanings in Australia: it is associated with drownings and disappearances, shark attacks, tidal waves and the things that lie unknown beneath the surface.

13 As Gelder and Jacobs (Uncanny Australia, p. 23) note, 'it is not simply the unfamiliar in itself which generates the anxiety of the uncanny; it is specifically the combination of the familiar and the unfamiliar - the way the one seems always to inhabit the other'.

14 Stoler, Ann (ed.) 2006, Haunted by Empire: Geographies of intimacy in North American history, Duke University Press, Durham, NC, p. 1. 
consequences in train, but he is neither pursued nor prosecuted. The narrative's disinterest in the question of crime and punishment-of identifying the murderer and bringing him to justice - parallels the national inquiry's sidelining of issues of guilt and responsibility. Unlike the national inquiry, however, the film is interested in the murkier moral territory of responsibility for past events, inherited guilt, apology and the possibilities and limits of forgiveness and reconciliation. ${ }^{15}$

After this disturbing opening, intensified by an elegiac musical score, the film shifts to the intimate lives of the white community in Jindabyne - the residents who identify as 'white Australian' regardless of their heritage, ethnicity or skin colour. Four of the men, representing the multiethnic legacy of the Snowy Mountains Scheme - Stewart, Carl, Rocco and the new initiate, Billy the Kidprepare ritualistically for their annual fly-fishing trip. The white community is haunted by its silenced and disowned past. Stewart, Claire and Tom initially appear as a happy unit, but the family has a troubled past. Stewart, an Irish immigrant and former rally champion, is concerned about losing his sexual attractiveness, which is exacerbated by Billy's youthfulness and easy openness. Claire, worried that she is pregnant, is inexplicably anxious. Her mother-in-law taunts her: 'It's not me that's ridden by the past.' Only later do viewers learn that Claire suffered from severe postnatal depression after Tom's birth and that she abandoned her baby and husband for 18 months, while Stewart's mother moved in to care for them. Claire's fear that she might uncontrollably repeat her past creates fragility in the family's relations. While Claire is too close to her past, Stewart is estranged from his. When his mother tells him that his sister has just left her second husband, he refers to it as 'women's business' unrelated to him. The unspeakable past that haunts the marriage metaphorically evokes the dislocated past of colonial violence and Indigenous dispossession. Whereas the white families stick to themselves, Carmel - of mixed Indigenous descentmediates between the various factions in the town.

This dislocated past is witnessed also through the film's representation of the Australian landscape. Like the scenes of Lake Jindabyne, panoramic shots of the majestic Australian Alps, which seem to roll on forever and be untouched by humans, convey the landscape as mysterious and sacred. When the men arrive in the isolated river valley, Billy stares in awe at the scene that unfolds in front of him. His gaze lingers on a line of intrusive electricity pylons - a reference to the hundreds of kilometres of tunnels and pipelines that run underground through this landscape. Arriving in the mountains, Stewart sings, 'In a hidden valley, in a hidden river', and Carl playfully interjects, 'full of blood'. While Carl refers to the fate of the fish, the song is ominously foreboding. When Stewart goes upstream to find a 'big one', he discovers Susan's nearly naked corpse face-

15 Falflak, Joel 2006, 'Introduction: whose guilt', English Studies in Canada, vol. 32, no. 1, pp. 1-10. 
down in the river. As Julia Kristeva has observed, the corpse- simultaneously familiar and strange, human and non-human - confronts the witness with the limits of his own humanity. ${ }^{16}$ Stewart's encounter with Susan's corpse produces in him a feeling of dread. When he first sees the body, he intuitively responds with Catholic rituals: he takes off his hat, mumbles 'Oh Jesus, oh Jesus', crosses himself and summons his mates with screams that resound through the valley. When the men turn Susan's body over, they see that she has been stabbed in the chest and presumably raped-desecrated like the landscape. After a brief exchange, they decide to leave her body in the river so it does not decompose and they tie her to a bush with fishing line so she will not float away. The fishing line, like the binoculars her murderer uses to trap her, is a potent signifier of her sub-human status. That evening, the men gather around the campfire eating, laughing and drinking, denying the uncanny effects unleashed by the presence of Susan's corpse. When the others are asleep, however, Stewart visits Susan's corpse, crossing himself and whispering a prayer, as if to ward away evil spirits.

The next day, the men continue fishing, relishing the remote location and the challenge of the catch. While they carefully preserve the fish, Susan's corpse floats nearby, alone and unmourned. In her analysis of 'grievable lives', Judith Butler argues that mourning serves as an indicator of the differential value we place on various lives and indicates lines of belonging, value and community. ${ }^{17}$ In contrast with deaths that are properly mourned and treated with respect and dignity, unmourned lives are signified as less than fully human. Moreover, as a prerequisite for reconciliation in settler nations such as Australia, nonIndigenous people must show respect for Indigenous losses by 'affirm[ing] the human worth and dignity of the persons who were harmed'. ${ }^{18}$ Although the men are not responsible for Susan's murder, by virtue of finding her body, they inherit the responsibility for responding appropriately. In failing to report her murder promptly, they refuse to take responsibility, treating her death as a mere inconvenience to be dealt with later. Read as national allegory, the film suggests that contemporary Australians might not be directly responsible for past violence and injustice against Indigenous Australians. Nonetheless, we have inherited the responsibility to respond ethically to these historical injustices. It is this entrenched liberal position that Peter Sutton, an anthropologist in remote Australia, has recently questioned: 'do all migrants acquire a guilty mantle as soon as they put a first step on Australian soil?'19

16 Kristeva, Julia 1982, Powers of Horror: An essay on abjection, Columbia University Press, New York, p. 3. 17 Butler, Judith 2004, Precarious Life: The powers of mourning and violence, Verso, London and New York. 18 Rice, Brian and Snyder, Anna 2008, 'Reconciliation in the context of a settler society: healing the legacy of colonialism in Canada', in M. B. Castellano, L. Archibald and M. DeGagne (eds), From Truth to Reconciliation: Transforming the legacy of residential schools, Aboriginal Healing Foundation, Ottawa, p. 47.

19 Sutton, Peter 2009, The Politics of Suffering: Indigenous Australia and the end of the liberal consensus, Melbourne University Press, Carlton, Victoria, p. 202. 
The white men are blind to the cultural and moral significance of their actions and fail to recognise their complicity in having breached the fragile boundaries of the moral and social community. The encounter with Susan's mutilated corpse, however, activates the uncanny. Susan's corpse-symbolising Indigenous ownership of the land-renders the men's beloved fishing spot 'strange' and forces them to retreat. When they return to town and report their find, they discover that their wives, girlfriends and other members of the community are horrified by their behaviour. While the local police officer scolds them, Carl invokes the protection of the white law, asking rhetorically: AAre you going to charge us with anything?' The local newspaper outs them with the headline: 'Men fish over dead body: Jindabyne outraged by cruel neglect of four local residents.' In a reversal of the opening sequence, the men are hunted by young Aborigines, who deface their homes and businesses - trashing Rocco's office and scrawling 'white hate crimes' in red paint on the windows. Even the white townspeople look at the men peculiarly. As a result of these unanticipated reactions, the men no longer feel at ease in their homes or the town; rather, they feel 'in place and "out of place" simultaneously'. ${ }^{20}$

The film explores the difficulty the white community has in acknowledging and mourning its own losses through a parallel narrative involving Stewart's and Carl's children. Caylin Calandria, the orphaned granddaughter of Jude and Carl, is grieving for her mother, who has recently died a stigmatised death. Jude, denying her need to work through her own grief for the loss of her daughter, tries to curtail Caylin Calandria's mourning rituals. Resisting Jude's imperative to forget her mother's death, Caylin Calandria acts out her need to observe the process of death, by soliciting innocent Tom to help her kill the class's pet guinea pig, and later, a small bird. The teacher, Carmel, recommends that Jude seek grief counselling for Caylin Calandria, herself and Carl, but Jude flatly rejects the suggestion. Jude, like Stewart, is suspicious of acknowledging the claims of the past. In a later scene, Caylin Calandria, simultaneously childlike and gothic, pretends to be drowning to encourage Tom - who she knows is terrified of the water - to swim in the lake. He nearly drowns, thereby drawing a parallel to Susan's corpse: it could have been Tom floating there.

\section{'White' Australia: between denial and empathy}

Given my broader argument - that Jindabyne mediates public responses to Bringing Them Home and the history it brings into visibility - it is worth pausing, at this stage, to link the film'srepresentation of denial and affective identification to the report's reception and responses to post-colonial injustice more broadly. 
In an essay that is relevant for analysing public responses to Bringing Them Home, Canadian scholar Deena Rymhs considers the ideological underpinnings of reconciliation processes and the interests they serve. In Canada, reconciliation commissions such as the Marshall Inquiry have been criticised as offering only a 'discursive balm for historical injustices that have profound, and potentially unsettling, political implications'.$^{21}$ Reconciliation processes present personal testimonies of suffering, which produce tragic narratives of Aboriginal history; these narratives position Indigenous people as victims, thereby denying Indigenous agency. Rather than engage with Aboriginal political demands and conceptions of justice, reconciliation commissions solicit an 'affective response' from the national community. These affective responses 'appropriate guilt', which 'is part of a larger cultural sensibility'. ${ }^{22}$ 'What results,' Rymhs argues, 'is a discursive re-enactment of past roles that overlooks the distance that Aboriginal people are asserting as they redraw notions of governance, political identity, and nationhood. ${ }^{23}$ She contends that '[s]uch semiotics would prompt us to be wary of affective identifications with indigenous history promoted by the process of reconciliation' ${ }^{24}$ Some of these same patterns - presenting a tragic version of Aboriginal history and soliciting an affective response from non-Indigenous Australians - are evident in the Bringing Them Home report.

The national inquiry into the Stolen Generations was not a truth commission. ${ }^{25}$ While it heard numerous testimonies from survivors, which broadly documented the harm, suffering and multi-generational trauma caused by child removal, it did not seek to corroborate testimony independently. Nor did it seek to identify individual perpetrators or hear testimony from those involved in the removal process. ${ }^{26}$ Rather, the national inquiry offered a limited opportunity for survivors to tell their stories and invited the Australian public to listen to these stories 'with open hearts and open minds, and to commit themselves to reconciliation' ${ }^{27}$ Thus, like the Canadian reconciliation commissions, it 'elided notions of guilt and responsibility' and instead focused on the need for the community to recognise and validate Indigenous suffering. ${ }^{28}$ While Bringing Them Home raised awareness of 'a relatively unknown negativity in Australia's

\footnotetext{
21 Rymhs, Deena 2006, 'Appropriating guilt: reconciliation in an Aboriginal Canadian context', English Studies in Canada, vol. 32, no. 1, pp. 105-24. She argued that in the wake of the Royal Commission on Aboriginal Peoples in 1996, social justice for First Nations peoples was imagined in terms of a Euro-Canadian discourse of reconciliation rather than recognising Aboriginal political concepts and desires.

22 Ibid., p. 109.

23 Ibid.

24 Ibid., p. 118.

25 For a discussion of how the national inquiry differed from a truth commission, see Rebecca Devitt's essay in this volume.

26 Bringing Them Home positioned the Stolen Generations as victims of racist assimilation policies. It positioned non-Indigenous Australians as belated witnesses to the history of colonisation and child removal, rather than as actively involved in executing assimilation policies, or in continuing colonising practices.

27 Wilson, Bringing Them Home, p. 3.

28 Ibid., p. 107.
} 
past... at the same time it enhanced victimhood as a basis of positive regard for Indigenous people' ${ }^{29}$ Australians were encouraged to respond empathically to the tragic version of Indigenous history that emerged from the report. They signed 'sorry books' in great numbers, expressing their regret for the suffering and pain caused by past policies, long before Rudd offered the national apology. These apologies, no doubt deeply felt, exemplify an affective response to Australian Indigenous history. As Rymhs warns, an affective response to a tragic version of Indigenous history can prevent us from recognising Indigenous agency and a conception of reconciliation grounded in the concept of Aboriginal self-determination. ${ }^{30}$

Jindabyne dramatises the various reactions of the white community to Susan's murder and the men's failure to report her death promptly. Read as national allegory, these responses - denial and affective identification-metonymically figure white Australian responses to a violent history of Indigenous dispossession, child removal and forced assimilation. In the film, however, these 'white' responses are gendered: they are signified as 'masculine' and 'feminine' in an oppositional framework, regardless of whether they are enacted by a male or female character. ${ }^{31}$ The 'masculine' response-distancing and denialis blind to issues of gender and race. Thus, the white men (and the women who identify with the position of white male privilege) regard Susan's murder as an isolated event. Stewart, Jude and Carl exemplify the subject position of the 'white Australian' who denies the claims of the past. For instance, when the policeman tells Carl and Jude that he would have expected them, having recently lost their own daughter, to understand how Susan's family and community are feeling, Jude angrily responds: 'We do understand, but that does not make us responsible.' Similarly, when Claire asks Stewart, 'What if it was Tom floating out there, would you think it was okay to leave him there?', Stewart responds defensively: 'It wasn't Tom; it was a stranger.' On a conscious level, Stewart is simply asserting a common view: that his ethics are based on a narrow conception of obligation to family and neighbours, rather than a more expansive notion of community. ${ }^{32}$ Later, when Alyssia declares that the men should not have been fishing on land that was sacred to Indigenous people, Stewart and Jude react defensively. Stewart dismisses Indigenous beliefs that

\footnotetext{
29 Ibid., p. 210.

30 I have explored some of the diverse ways in which non-Indigenous Australians have responded to Stolen Generations testimony; see Kennedy, Rosanne 2004, 'The affective work of Stolen Generations testimony: from the archives to the classroom,' Biography, vol. 27, no. 1, pp. 48-77.

31 The explicit gendering of denial and identification in the film draws attention to the gendered dimensions of the reception of Bringing Them Home, and particularly the way white Australians were asked to identify with the position of the vulnerable mother and the suffering child. See Kennedy, Rosanne 2008, 'Vulnerable children, disposable mothers: Holocaust and Stolen Generations memoirs of childhood', Life Writing, vol. 5, no. 2, pp. 161-84.

32 Notions of moral obligation are discussed in Singer, Peter 2002, One World: The ethics of globalization, Yale University Press, New Haven, Conn.
} 
the spirits of the dead float through the mountains as 'superstitious' - a view that is questioned by the film's representation of his own Catholic rituals and beliefs. Jude insists pragmatically that they all pay taxes to support the national park, and thus, they all have a right to enjoy it.

Whereas Stewart, Carl and Jude fail to connect Susan's murder and the men's disrespectful behaviour to a history of racial, sexual and colonial violence, Claire views these incidents primarily through a gendered moral and emotional framework. She exemplifies an affective response, which is grounded in her identification with Susan as a victim of male sexual assault, and in her guilt about Stewart's disrespect. Claire suggests to Stewart that if Susan had been 'a boy', the men would have taken the body out of the river and covered it up. When she realises that Stewart made love to her before reporting Susan's murder, she imagines that the sight of Susan's naked corpse aroused him. She sees herself as a mere vehicle for him to act out his lust, rather than as desired in her own right. Thus, in her view, his disrespect towards Susan is passed on to her. Focused on herself, she ignores important differences in her and Susan's subject positions as white and black women. These differences are manifested in a later scene: on her way to Susan's funeral, Claire is pursued but spared by Susan's murderer, and is thus not quite a victim. Claire's misplaced identification with Susan causes her to breach the protocols of respectful mourning. Driven by her need 'to know what happened' to Susan, and her lingering suspicions that the men defiled her corpse, Claire goes to the morgue and inspects Susan's body for evidence, as if it is simply an exhibit. In response to the men's narrowly legalist conception of obligation, Claire aims to heal divisions in the community. Thus, she tells her son that 'when something bad happens, we all have to do something good, no matter how little'.

Both of these positions - masculine distancing and feminine identificationignore race. Carmel, of Aboriginal descent, brings the issue of race to the fore; she regards the men's casual response to Susan's murder as a repetition of a long history that normalises sexual violence against black women. When she finds out what happened in the mountains, she shouts angrily at Rocco, her boyfriend: 'It was a black woman, you didn't say that, why didn't you say that?' In contrast with Claire's moralistic response, Carmel advocates racial and cultural respect. Horrified by Claire's disrespectful act of going to the morgue to inspect Susan's body, she admonishes her: 'It's not about you, Claire.' Claire responds aggressively: 'Isn't it about all of us?' Through Carmel's criticism of Claire, Jindabyne shows the affective, 'feminine' response to be paternalistic and self-absorbed, rather than responsive to Indigenous desires. While Carmel is critical of Claire's naive attempt to 'do something good', she also rejects the male approach to resolving issues through combat rather than negotiation. Thus, 
when Rocco, provoked by Stewart's dismissive comment about Indigenous beliefs, punches Stewart and breaks his nose, Carmel angrily tells Rocco that she can fight her own battles.

Through the figure of 'the stranger', which it is worth revisiting, the film bears uncanny witness to the imaginary relations that underpin notions of national belonging and exclusion. In response to Claire's questions, Stewart unwittingly refers to Susan as a 'stranger' - someone he does not know personally, but also, someone who is foreign, who does not belong. Of course, it is only as a consequence of the ideological work of settler-colonialism - the way it naturalises the Anglo-European as 'belonging' to Australia and Indigenous people as 'strangers' in their own land - that Stewart, an immigrant to Australia, is able to regard Susan, a native of Australia, as a 'stranger'. Thus, his identity as an Irish immigrant - a 'foreigner' — can appear entirely coincidental, simply a matter or his Irish accent. It uncannily signifies, however, the inversion of the positions of native and stranger. In the imagined settler-colonial nation of Australia, Indigenous peoples are 'strangers' and white 'foreigners' naturally belong. This, of course, is a post-colonial inversion that can only ever be unstable and unsettling. Claire, with her American accent, is also positioned as a foreigner, the stereotype of the 'do-good' American who naively wants to make things right in the community.

The film goes beyond simply dramatising the positions of denial and guilt; through its use of the figure of 'the stranger' it links Stewart's denial to his psychic estrangement and alienation. The figure of the stranger, read through a Kristevan frame, invites viewers to interrogate the psycho-dynamics of relations of self/other as they play out across a boundary of cultural difference and historical injustice. Kristeva argues that the stranger is not simply the external 'other'. Rather, '[s]trangely, the foreigner lives within us: he is the hidden face of our identity, the space that wrecks our abode, the time in which understanding and affinity founder'.$^{33}$ As Kristeva points out, however, 'the foreigner comes in when the consciousness of my difference arises, and he disappears when we all acknowledge ourselves as foreigners, unamenable to bonds and communities' ${ }^{34}$ The theme of Stewart's estrangement from himself is explored in earlier scenes with his mother and Claire. It is only, however, when Stewart comes face to face with Susan's 'otherness' - signified not only through racial and sexual difference from him, but through her status as no longer living - that a series of unsettling events forces him to confront his estrangement from himself and his past. ${ }^{35}$

33 Kristeva, Julia 1991, Strangers to Ourselves, Translated by Leon S. Roudiez, Columbia University Press, New York.

34 Ibid, p. 1.

35 Kristeva adds that '[i]t is through unravelling transference - the major dynamics of otherness, of love/ hatred for the other, of the foreign component of our psyche - that...I become reconciled with my own otherness-foreignness, that I play on it and live by it'. 
Stewart's home becomes 'unhomely' as Claire scorns him and refuses his touch. Stewart does not feel that he should have to explain or justify his behaviour to Claire. He regards her reaction to his behaviour as irrational and 'hysterical'; she accuses him of 'fucking like a robot' and behaving as if he is on automatic pilot. He sees the breakdown of the marriage as a result of her insistence in turning the men's failure to report Susan's murder promptly into a moral crisis that must be talked through and resolved. From Claire's perspective, however, Stewart's failure to grasp the significance of his actions is a manifestation of his alienation from himself, his past, their past together and their marriage, which she cannot tolerate. For her, the crisis in the marriage can be resolved only through some gesture of atonement from Stewart to the Indigenous community, which she believes will help to heal the rift between them.

Stewart's indifference to Susan's murder, to the collective interest, to community and the past, enacts the estranged condition of black/white relations in the town and surrounding bush. Like Meursault in Camus' The Stranger, Stewart is a 'subject for whom history has no meaning'. ${ }^{36}$ Whereas Stewart presumes his innocence in relation to the past, Claire-perhaps with unresolved guilt in relation to her previous abandonment of her family-appropriates guilt. She sees herself, and other white Australians, as 'guilty', and thus attempts to atone for her husband's failure to show respect. She collects money in town for Susan's funeral, making the white townspeople uncomfortable, and delivers the money to Susan's home. The Aboriginal women reject Claire's gesture and the town's money. Claire, exemplifying a common subject position in the broader white community, has 'good intentions' but she imagines moral community unilaterally, on her own terms. She does not ask the Aboriginal community what reparation or response would be welcome; she decides herself, and often offends through her actions. As Gelder and Jacobs propose: 'Paradoxically, the former position casts non-Aboriginal Australians as "out of place", uninvolved in those formative colonial processes: while the latter position would conceive of non-Aboriginal Australians as...too involved, too embedded in place. ${ }^{37} \mathrm{~A}$ recent immigrant, Stewart is 'out of place', refusing to recognise his implication in Susan's murder by virtue of being a beneficiary of colonisation. He fails to see that, as a new Australian, he 'automatically inherits the (mis)fortunes of Australia's colonial past'.$^{38}$

The narrative of Claire and Stewart's disintegrating marriage - characterised by distrust and alienation-mediates and reflects the narrative of tense relations between Indigenous and non-Indigenous people in small-town Australia. ${ }^{39}$

\footnotetext{
36 Penny, The Psychoanalysis of Race, p. 129.

37 Gelder and Jacobs, Uncanny Australia, p. 24.

38 Ibid.

39 As Kristeva (Strangers to Ourselves, p. 190) points out, there can be a psychological cost to denying the uncanny: 'Such an elimination of the strange could lead to an elimination of the psyche, leaving...the way
} 
Jindabyne represents relations between Indigenous and non-Indigenous Australians as tense and hostile-like Stewart and Claire's marriage. The Indigenous and non-Indigenous communities do not mix easily; they remain in their separate worlds, and when they meet, it is in a situation of conflict. Dialogue across cultures is engaged in with distrust and communication is severely limited. The film represents Australia as composed of two divided peoples — 'two separate nations' — living in one nation-state.

\section{The limits of post-colonial apology: between mourning and justice}

What makes Jindabyne especially relevant to contemporary debates about reconciliation is the staging of a climatic scene of apology, which takes place during an Indigenous mourning ceremony. Claire, who has left Stewart, goes to Susan's funeral, which is held on sacred Aboriginal land. When Claire arrives, several young Aboriginal men angrily demand that she leave, making her aware that she is 'out of place'. Susan's aunties, however, intervene and allow her to stay. She stands at a distance, paying her respects. Carmel is also present, standing alone. In the centre of the circle, there is a tower constructed from branches and leaves, which shields a fire. The smoke from the fire wafts through the valleys and is believed to carry away the spirit of the dead person. The Indigenous men beat a rhythm with percussion sticks and sing in their language. A little later, Stewart, Carl, Rocco, Jude and their children arrive. In a scene of heightened tension, Stewart walks into the centre of the group of mourners and Susan's father comes forward. Stewart identifies himself as the one who found Susan's body and apologises. Rather than confer forgiveness, Susan's father throws dirt in the air in front of Stewart's face, slaps him across the shoulder and spits at his feet. He then returns to the mourning circle. Stewart quietly tolerates this humiliation before walking towards Claire, who joins him. A young Aboriginal woman eases the tension by singing a love song Susan had written shortly before she died. Meanwhile, Susan's murderer lurks unseen behind rocks, watching the funeral from a distance.

As the woman sings, the camera pans to close-ups of groups of Aboriginal mourners whose characters have not been developed in the narrative. It then pans slowly from Carmel (the figure who mediates between black and white) and Tom (the innocent white child) around the white participants, moving from Rocco, to Jude, Carl and Caylin Calandria, and finally, to Claire and Stewart. As the singing continues, Caylin Calandria waves a branch and whispers 'Be gone', which Jude repeats - as if they are farewelling the spirit of their

open to acting out, including paranoia and murder.' 
own lost mother/daughter. The ceremony is clearly healing for the family, as Carl and Jude hold each other's gaze meaningfully. As the singer stalls on the words 'as I love you', Stewart tells his wife: 'I want you to come home, Claire.' This scene, read in light of Rymhs' critique of an Anglo-European discourse of reconciliation, offers an allegory of how apologies for past sufferings function: even when rejected by the Indigenous community, the apology has value in the moral economy of the white community. Although Susan's father rejects Stewart's apology, the mourning ceremony enables Carl, Jude and Caylin Calandria to put their own ghosts to rest and to become reunited and stronger as a family. It also seeds Stewart's reconciliation with his wife. ${ }^{40}$ In short, a black woman's murder and funeral becomes an opportunity for catharsis and healing in the white community.

This scene ironically recalls Carmel's warning to Claire: 'It's not about you, Claire.' Apparently, for the white community, it is about them in that the events stemming from Susan's murder enable them to confront the unfinished business in their personal pasts, to grieve for their losses and move on with their lives. The black and white communities, however, remain separate and estranged and the film ends without redemption or closure. In the final scene, the presumed murderer, sitting in his truck, comes into view. A bee buzzes around inside the truck, repeating the opening soundtrack, and the murderer smacks it abruptly. Indigenous Australians may cringe at the film's representation of Aborigines as unforgiving and resentful. It is therefore important to acknowledge that the film offers a non-Indigenous representation of an Indigenous response to apology. We should not assume that the 'rejected apology' scene represents an Indigenous perspective. Rather, it can be read more precisely as dramatising white anxiety about not being forgiven for dispossessing and disenfranchising Indigenous peoples, or as conveying a white view that Aboriginal people should not forgive without reparations or justice.

While I have argued that the apology functions cathartically for the white community, it is worth reflecting further on the significance of the apology scene in the broader context of debates about reconciliation and forgiveness. For viewers, the slap Stewart receives is unexpected; other films with similar scenes of apology, such as Aussie Rules and Japanese Story, lead the viewer to expect forgiveness. What other frameworks might be productive for teasing out the meanings of the slap and the rejection of apology? The refusal to confer forgiveness? In blogs about Jindabyne, some viewers regard the slap simply as a politically correct humiliation of the white man. The murderer's lurking presence during the apology scene, however, reminds viewers that there is 'unfinished

40 As Rymhs ('Appropriating guilt', p. 108) points out, 'The success always implied by the act of reconciliation dissolves the wronged subject's agency as the public, the government, and its institutions forgive themselves.' 
business', and raises the issue of justice and retribution. As Nancy Kluger points out with regard to the Holocaust, 'it would seem that some retribution, some "buying back" has to take place before forgiveness can set in' ${ }^{41}$ The slap might express the Indigenous father's attempt to avenge the white men's disrespectful treatment of his daughter. The slap and the presence of the murderer prompt further questions: should non-Indigenous Australia expect forgiveness when justice has not been achieved? When reparations have not been offered? The slap reminds viewers 'that asking for forgiveness does not imply the granting of it' ${ }^{42}$ After all, the murderer is still at large, and 'when the reconciliation process ignores the issue of responsibility, it forgets that forgiveness may not be granted'. ${ }^{43}$

It is significant that the apology is offered during a mourning ceremony - a setting that invites viewers to reflect on the entanglements of apology, reconciliation and mourning. Heidi Grunebaum, writing in the wake of the South African Truth and Reconciliation Commission, suggestively reflects on the significance of 'non-forgiveness':

Between understanding and retribution remains the disavowed process of deferral and of mourning. In this deferral, non-forgiveness can be installed, not as a threat of retribution or vengeance but as the reclamation of selfhood and dignity on one's own terms. The moral defence of not forgiving lies in the fact that 'the primary value defended by the passion of resentment is self-respect, resentment being tied to individual's self-respect or self-esteem'.$^{44}$

In light of Grunebaum's comments, we can read the Indigenous man's slap of rejection as an assertion of his self-respect, rather than as vengeance or retribution. Susan's father preserves his agency by refusing to forgive when justice has not been achieved. In rejecting Stewart's apology, he refuses to let Stewart and his friends, and by extension the broader white community, absolve themselves of responsibility. On this reading, the slap can be viewed as an embodied act of testimony. Susan's father does not speak; he communicates through the embodied actions of slapping and spitting. His silence, together with his actions, returns us to Gayatri Spivak's question: can the subaltern speak, or, under what conditions can the subaltern be heard? Commenting on the implications of Spivak's question for testimony, Len Findlay observes that 'the subaltern's silence performs both the blocking of testimony as speech

\footnotetext{
41 Kluger, Nancy 2002, 'Forgiving and remembering', PMLA, vol. 117, no. 2, p. 312.

42 Rymhs, 'Appropriating guilt', p. 108.

43 Ibid.

44 Grunebaum, Heidi 2002, "Talking to ourselves "among the innocent dead": on reconciliation, forgiveness, and mourning', PMLA, vol. 117, no. 2, p. 308.
} 
and the fuelling of testimony in the idiom of embodiment' ${ }^{45}$ Through his embodied testimony, Susan's father resists being positioned as the victimised other and ensures that his words will not be appropriated within a Euro-Anglo framework of reconciliation. He stands as a figure of resistance to the colonising bureaucratic institutions that underwrite formal reconciliation processes and that seek to promote reconciliation without justice.

Grunebaum's insights into forgiveness and reconciliation stem from her experience as a South African, exploring issues of mourning and forgiveness in the aftermath of the South African Truth and Reconciliation Commission. As Andreas Huyssen has argued in his reflection on contemporary cultures of memory, memory is always, ultimately, national memory. ${ }^{46}$ To explore the ways in which the apology scene anticipates and mediates national events, I will consider it in relation to Peter Sutton's recent, controversial analysis of the 'breakdown of liberal consensus' regarding reconciliation and Aboriginal selfdetermination in post-apology Australia. He argues that a formal reconciliation process is presumed on the assumption of Indigenous and non-Indigenous peoples as divided and living in 'two separate nations' in one nation-state. In his view:

[T] he danger is that formal agreements [such as a treaty] will only serve to entrench the separation of Indigenous and non-Indigenous people, and would do so in an era when the fragile achievement of social cohesion is once again on the table as a precious thing to be shielded and fostered, not merely assumed. ${ }^{47}$

He therefore favours practising reconciliation as a 'personal conscience vote', as something that individuals do, rather than as a formal state process. In Jindabyne, Stewart offers a personal apology, but it is not simply a "personal conscience vote'; rather, it functions symbolically as an analogy for a formal, national apology. The personal apology is offered in the context of a culturally specific mourning ceremony, which is both a public and an intensely private event. It is held on land of sacred significance to Indigenous people, but not publicly recognised as 'Aboriginal land'. Thus, the land itself is marked as traversed by two cultures. Most significantly, Indigenous and non-Indigenous Australians constitute a 'witnessing public': they witness Stewart's apology, making it a 'public' event.

\footnotetext{
45 See Findlay's essay in this volume.

46 Huyssen, Andreas 2003, Present Pasts: Media, politics, amnesia, Stanford University Press, Stanford, Calif.

47 Sutton, The Politics of Suffering, p. 203.
} 
Sutton outlines two views of a formal reconciliation process in Australia that provide contrasting frames for reading the rejected-apology scene. On the one hand:

[Reconciliation] offers the comfort of company and the strength of numbers. It offers a kind of mass Bridge walk, crossing off a painful chapter on behalf of all the citizenry...It also offers conjoint catharsis, an authorised shedding of guilt, possibly a sanctioned regaining of innocence. Confession followed by penitence and absolution. ${ }^{48}$

Claire approaches reconciliation as an opportunity for a shared shedding of guilt and mourning losses. Keen to foster community, she invites the others to join her. When they do, the apology provides opportunity for healing and catharsis for the white community.

Sutton also identifies what he calls a 'less lofty view' in which 'collective Reconciliation is about the politics of appeasement':

[I]t is only by coming to some kind of compact between settler descendants and First People that the insistent negatives of Indigenous criticism, the culture of complaint... will be silenced. This view suggests that reconciliation is something the non-Indigenous have to do, while the Indigenous sit back gratefully silent or merely nod their acceptance or just don't want to hear, or, in some cases, spit back our solicitude. But surely that is not Reconciliation, that is more an apology. ${ }^{49}$

Is it this rather bleak view — 'apology as appeasement' - that Jindabyne predicts: a future in which an apology is offered but forgiveness is not conferred? In this view, Indigenous and non-Indigenous people do not come together to reconcile past differences. Rather, non-Indigenous Australians apologise, somewhat reluctantly, for crimes they do not feel equally responsible for, under the watchful moral gaze of their fellow white Australians. Indigenous people do not want to hear their apologies and spit them back. In practice, Rudd's apology was well received, at least by those present at Parliament House on the day, and there was no sense of tension or bitterness. Indeed, many members of the Stolen Generations and their families expressed relief. Sutton points out, however, that in the wake of the apology, there has been no formal response or acceptance by Indigenous people. At the same time, it is important to note, in response to Sutton's analysis of appeasement, that Jindabyne insists - through the disturbing presence of the murderer lurking on the edge of the funeralthat there can be no reconciliation without justice. In the final analysis, then, the rejected-apology scene invites several different readings: 1) as a cathartic act for 
the white community; 2) as a means for the Indigenous community to preserve self-respect by refusing to confer forgiveness without justice or mourning; 3) as an act that seeks to appease and silence Indigenous grievance, and to enforce closure on an unsettling past.

\section{Conclusion: Jindabyne as uncanny witness}

In reflecting on how nations respond to the divided legacies of historical injustice and loss, Dominick LaCapra distinguishes between 'acting out' and 'working through'.$^{50}$ By working through, he refers to the need for nations to find some way of breaking out of a traumatic repetition of cycles of violence, retribution and complaint. These forms of 'working through' can range from truth commissions to artworks and memorials. Through a narrative structure that traumatically acts out and repeats the past, Jindabyne explores the blockages and failures of understanding that prevent Indigenous and non-Indigenous Australians from working through the gains and losses that divide them. The working through that is achieved is limited and partially blind, serving only to reconcile Stewart and Claire, but not Indigenous and non-Indigenous communities. Indeed, the mood of the apology scene is tense and unforgiving. The Indigenous men are hostile to the white folks, who appear contrite, but who naively fail to grasp the depth of Indigenous resentment and anger.

The apology scene in Jindabyne brings to the surface a future that awaits us when apology is offered without regard for justice. Given the events that have transpired in Australia in the three years since Lawrence's film was released, the film's representation of the refusal of justice on the one side, and the withholding of forgiveness on the other, is uncanny. While the national apology has been an important symbolic gesture, and has been welcomed by many Indigenous Australians, the work of achieving social justice remains. Indeed, despite the fact that Australia (belatedly) signed the United Nations Declaration on the Rights of Indigenous Peoples (2007), it has suspended some rights for Indigenous Australians in the name of a controversial 'emergency intervention' in the Northern Territory. The intervention is delivering some positive benefits for Indigenous communities and has been welcomed by many, particularly Indigenous women. Nonetheless, it has come at a cost, and has undoubtedly contributed to the demise of Indigenous rights and the principle of self-determination for Indigenous Australians. The Northern Territory intervention, and the impatience with rhetoric of Aboriginal sovereignty, might be symptomatic of the entrenched Australian habit of 'forgetting' the past-

50 LaCapra, Writing History, Writing Trauma, pp. 44-5. 
of forgetting that dispossession, loss and trauma continue to reverberate in the present, impacting particularly on Indigenous Australians with the fewest resources to respond.

We are now in a position to return to Poovey's point: that cultural objects are valuable for how they imagine our relation to a remembered past and an anticipated future. ${ }^{51}$ I propose that Jindabyne anticipates a post-apology future, in which an apology is offered before justice for Indigenous Australians has been achieved. As a result of white Australia's failure to confront issues of justice and responsibility, when an apology is offered, it is received passively. No formal acceptance is offered. No dialogue is entered into. Sutton argues that '[t]he trauma of raking over the past has to be compensated for by something truly significant, if it is to be taken on'. Apologies, however, require no more justification than 'simple decency' and 'don't seem to have changed anything much in the world'. ${ }^{52}$ Simple decency is what Claire seeks when she tells the priest that she just wants her husband to 'be a good man'. But the film suggests that decency is not an adequate response to the traumas and injustice Indigenous Australians have suffered. As Jindabyne anticipates, in the aftermath of a national apology offered without reparation or compensation, the Australian nation remains in a condition of stalled reconciliation.

In closing, it is worth repeating Grunebaum's observation that

forgiveness relate[s] to memory and recognition...not as a right, a claim, or a demand but as the deferred outcome of a long process that includes mourning the loss, honouring the dead, restituting the land, and reclaiming the language of resistance and survival over the silence of abjection, trauma, and despair. ${ }^{53}$

The current silence towards reconciliation in Australia reveals considerable impatience with the long process required to work through the past.

51 Poovey, 'The twenty-first century university and the market', pp. 1-16.

52 Sutton, The Politics of Suffering, p. 196.

53 Grunebaum, 'Talking to ourselves "among the innocent dead"', p. 308. 